\title{
IMPORTANCE OF THE EVALUATION OF SERUM ALBUMIN CONCENTRATION IN POSTOPERATIVE PERIOD OF PATIENTS SUBMITTED TO MAJOR SURGERIES
}

\author{
Importância da avaliação da concentração da albumina sérica no pós-operatório de operações \\ de grande porte
}

Luiz Ronaldo ALBERTI, Andy PETROIANU

From Alfa Institute of Gastroenterology of the Hospital of Clinics of the Federal University of Minas Gerais - Postgraduate Nucleon of Santa Casa de Belo Horizonte, Belo Horizonte, MG, Brasil.

HEADINGS - Postoperative period. Serum albumin.

\section{Correspondência: \\ Andy Petroianu \\ e-mail: petroian@medicina.ufmg.br \\ Fonte de financiamento: National Council of Science and Technology (CNPq) and Foundation for Assistance to Research of Minas Gerais (FAPEMIG) \\ Conflito de interesses: não há}

Recebido para publicação: 01/10/2009 Aceito para publicação: 14/01/2010

DESCRTORES - Período pós-operatório. Albumina sérica.
ABSTRACT - Background -The prevalence of protein-energy malnutrition in surgical patients is high, ranging from $10 \%$ to $54 \%$. The correct assessment of the nutritional status of such patients is crucial since malnourishment is a risk factor for morbidity and mortality. Aim - To assess the effect of surgical trauma in serum albumin concentration during the immediate postoperative period of major surgeries. Methods - The study was conducted on 100 randomly chosen adult patients submitted to elective major surgeries, classified according to sex, age and skin color. Blood samples for the determination of serum albumin concentrations were obtained on the days before and after the surgical procedure. Results - There was a reduction in serum albumin from $3.72 \pm 0.47$ to $2.83 \pm 0.71 \mathrm{~g} / \mathrm{dL}(\mathrm{P}<0.0001)$ with no difference in sex or skin color for major surgeries. With respect to age groups, a greater drop in albumin was observed among patients aged over 65 years, followed by younger patients $(<45$ years), and finally by patients aged 45 to 65 years. Conclusion - Major operations lead to acute reduction in albumin concentration in the immediate postoperative period, and it was more intense in patients aged over 65 years.

RESUMO - Racional -A prevalência de desnutrição energético-protéica em pacientes cirúrgicos é alta, variando entre $10 \%$ a 54\%. A correta avaliação do estado nutricional desses pacientes é crucial uma vez que a desnutrição é um fator de risco para a morbidade e mortalidade. Objetivo - Avaliar o efeito do trauma cirúrgico na concentração sérica de albumina, durante o período pós-operatório imediato de operações de grande porte. Métodos - O estudo foi conduzido em 100 pacientes escolhidos aleatoriamente adultos submetidos a procedimentos cirúrgicos eletivos de grande porte, classificados de acordo com sexo, idade e cor da pele. As amostras de sangue para a determinação da concentração sérica de albumina foram obtidas nos dias antes e após o procedimento cirúrgico. Resultados - Houve diminuição da albumina sérica de 3,72 $\pm 0,47-2,83 \pm 0,71 \mathrm{~g} / \mathrm{dL}(\mathrm{P}<0,0001)$, sem diferença de sexo ou cor da pele para operações de grande porte. Com relação à faixa etária, a maior queda da albumina foi observada entre os pacientes com idade superior a 65 anos, seguidos pelos pacientes mais jovens ( $<45$ anos) e, finalmente, pacientes com idade entre 45-65 anos. Conclusão - As grandes operações levam à diminuição aguda na concentração de albumina no pós-operatório imediato, que foi mais intensa nos pacientes com idade superior a 65 anos.

INTRODUCTION

$\mathrm{T}$ he prevalence of protein-energy malnutrition in surgical patients is high, ranging from $10 \%$ to $54 \%$. The correct assessment of the nutritional status of such patients is crucial since malnourishment is a risk factor for morbidity and mortality 1,2,4,10,17.

The identification of patients with a high surgical risk is essential in the operative indications and decisions, often limited by the potential morbidities and mortality related to the procedure. Hence, the clinical and laboratory parameters which may point out higher risk for postoperative complications are important ${ }^{9}$.

As from the 1970 's, researchers tried to define the risk factors for 
the different major surgeries ${ }^{3,7}$. Malnourishment is reported in $40 \%$ to $50 \%$ of hospitalized patients, with higher risk factor for postoperative infections and healing complications in patients who undergo major surgeries ${ }^{5}$. Subsequent studies assessed the effect of therapeutic nutrition, especially total parenteral nutrition aiming to minimize operative risks ${ }^{17}$.

The surgical aggression, besides local alterations, results in systemic reactions mediated by organic adjustment to the new condition and by response to trauma. This set of factors is called post-traumatic acute phase reaction and is characterized by endocrine and metabolic changes, release of adrenal and pituitary mediators, leading to an increase in protein and lipid catabolism, non-glucose related hyperglycemia and salt and fluid retention ${ }^{2,13}$.

Among the systemic responses, hepatocyte response stands out, with decreased synthesis of albumin and ferritin. On the other hand, there is an increase in serum C-reactive protein concentration, ceruloplasmin and other proteins related to the immune processes ${ }^{6,13}$. Specifically, albumin is a protein synthesized by the liver, with a long mean life (21 days), hence variations in its concentration during a short interval can not be explained by nutrition or liver function alterations ${ }^{17}$. Some studies showed that serum albumin lower than $3 \mathrm{~g} / \mathrm{dl}$ was followed by anergia as well as by more frequent and severe postoperative complications, and that parenteral nutrition improved the reactive state in delayed hypersensitivity skin test and decreased the number of postoperative complications ${ }^{2,8,11,16,17}$. Nevertheless, we did not find any publications evaluating albumin concentration in the immediate postoperative period.

Considering the need for new subsidies for the study of systemic repercussion after surgical trauma, this study aimed to assess the effect of major surgeries in the postoperative albumin concentration.

\section{METHODS}

This research followed the recommendations of the Helsinki Declaration and Resolution number 196/96 from the Brazilian Ministry of Health on research involving human beings and was approved by the Research Ethics Committee of the Universidade Federal de Minas Gerais (UFMG) ${ }^{12}$.

One hundred adult patients were assessed prospectively, 50 men and 50 women, seen at the Department of Digestive Surgery at Hospital Júlia Kubitschek, Hospital das Clínicas - UFMG, and Hospital Mário Penna, in the city of Belo Horizonte, Minas Gerais, Brazil.

The patients were submitted to the following surgeries, classified according to the literature as major surgeries ${ }^{16}$ : gastrectomy, esophagectomy, colectomy, abdominoperineal amputation, hepatectomy, duodenopancreatectomy, herniorraphy, transduodenal papillotomy and porta-azygos disconnection for varices.

The blood samples were collected in the previous and following day of the surgical procedure to dose serum albumin along with routine exams. The biuret method and bromocresol green were used, and serum albumin reference levels ranged from $3.5 \mathrm{~g} / \mathrm{dL}$ to $5.5 \mathrm{~g} / \mathrm{dL}^{2}$.

Some epidemiologic parameters, such as age, sex and skin color (white, brown and black) were compared, with the objective of correlating the surgical influence in albumin in different population groups.

Patients who had been submitted to radiation therapy or chemotherapy for cancer, blood transfusion within the last six weeks, preoperative parenteral nutrition, emergency surgery, who had chronic liver disease or coagulation disorders were excluded. Following the preoperative routine assessment, all patients included in this study went through a complete history taking and physical examination, chest X-ray, electrocardiography, complete blood count, coagulation tests, glycemia, liver function tests and urine analysis. Other laboratory exams were ordered whenever necessary.

The pre and postoperative albumin results were compared using the Student's t test for paired samples. Sex comparison was done using the Student's t nonpaired test. Comparisons regarding age and skin color between the groups were performed using variance analysis test (ANOVA) for repeated samples, followed by the Tukey-Kramer test. Differences were considered as significant when the $p$ value was $<0.05$.

\section{RESULTS}

Age ranged from 16 to 89 years, with a mean of $51.17 \pm 12.2$ years. There was no difference between the age of men ( $54.12 \pm 15.3$ years) and women (48.6 \pm 12.7 years). (Table 1 )

TABLE 1 - Serum albumin concentration $(\mathrm{g} / \mathrm{dl})$ (mean \pm standard deviation) during the preoperative and postoperative period of major surgeries according to gender, skin color, and age

\begin{tabular}{|c|c|c|c|}
\hline & \multicolumn{2}{|c|}{ MAJOR SURGERIES $(\mathrm{N}=100)$} & \multirow[t]{2}{*}{ P VALUE } \\
\hline & $\begin{array}{c}\text { Preoperative } \\
\text { Period }\end{array}$ & $\begin{array}{c}\text { Postoperative } \\
\text { period }\end{array}$ & \\
\hline SEX & & & 0.327 \\
\hline Male & $3.74 \pm 0.46$ & $2.86 \pm 0.64$ & \\
\hline Female & $3.63 \pm 0.48$ & $2.81 \pm 0.49$ & \\
\hline SKIN COLON & & & 0.5029 \\
\hline White & $3.65 \pm 0.64$ & $2.82 \pm 0.63$ & \\
\hline Brown & $3.61 \pm 0.82$ & $2.79 \pm 0.61$ & \\
\hline Black & $3.85 \pm 0.63$ & $2.83 \pm 0.74$ & \\
\hline \multicolumn{4}{|l|}{ AGE } \\
\hline$<45$ years & $3.69 \pm 0.51$ & $2.88 \pm 0.37$ & \\
\hline $45-65$ years & $3.47 \pm 0.38$ & $2.91 \pm 0.59$ & \\
\hline$>65$ years & $3.74 \pm 0.57$ * & $2.64 \pm 0.32$ * & 0.0006 \\
\hline
\end{tabular}

* Difference between pre and postoperative periods of major surgeries for patients older than 65 y.o., significant for $p<0.0006$ (paired $t$ test) 
According to the data assessed, 39 patients were white (39\%), 38 mulatto (38 \%) and 23 black (23\%).

Table 1 depicts serum albumin values in the pre and postoperative period of the major surgeries of patients studied, according to age, sex and skin color.

Serum albumin dropped in the postoperative period of patients submitted to major surgeries from $3.72 \pm 0.47$ to $2.83 \pm 0.71 \mathrm{~g} / \mathrm{dL}(P<0.0001)$.

There was no difference between sexes in the postoperative albumin drop $(P=0.327)$.

As to skin color, there was no difference in albumin decrease (ANOVA, $P=0.5029$ ).

About the different age groups, there was a more significant drop in albumin in patients aged over 65 years, followed by those younger than 45 , and lastly, those aged between 45 and 65 years, who had the least reduction $(P=0.0006)$.

\section{DISCUSSION}

Since organic defense decrease and malnutrition were recognized as potential factors for higher morbidity and mortality rates in the postoperative period, many studies have dealt with the early detection of immunosuppression and malnourishment in surgical patients ${ }^{3,6}$. Malnourished patients are at higher risk of postoperative complications and death, if compared to well-nourished patients submitted to similar surgeries. Besides, nutrition therapy has improved clinical prognosis and quality of life 8 . These data are important in the sense of proposing an effective treatment for nutritional control, aiming to decrease operative morbidity and mortality 1,3,15. Most trials compared the results of clinical parameters with results observed in the postoperative period. Nevertheless, we did not find in the literature the quantification of albumin variation according to surgical procedures.

Major trauma, including surgical, are often followed by tissue and systemic inflammatory reactions, mobilizing much fluid to the interstitial and intravascular spaces. This response to trauma is followed by decreased serum albumin concentration ${ }^{1,14,16}$.

Patients who underwent porta-azygos disconnection for portal hypertension were included in the study. Usually such patients have severe liver dysfunction with albumin problems. For the present study, only patients with schistosomiasis portal hypertension with no other disorder were included, having normal liver function, including normal protein levels.

Hypoalbuminemia may be partly explained by alterations in vascular permeability and by dilution effect secondary to intravenous infusion of saline and glucose solutions during surgery and the immediate postoperative period ${ }^{8,11}$. While water excess is rapidly eliminated, sodium overload is slowly excreted, leading to more prolonged extracelular fluid dilution and, as a consequence, albumin dilution. The greater change in serum albumin level, which is proportional to that of hemoglobin, suggests that the distribution of protein compounds plays a crucial role on this process ${ }^{13}$. The literature indicates that severity of the catabolic injury leads to a proportional increase in vascular permeability 5 .

Alterations in bioimpedance also have an impact in the hydroelectrolytic content and change protein concentration. The inflammatory phenomena that follow surgery and trauma lead to tissue edema with protein leakage to the interstitial space ${ }^{13}$. This albumin release from the capillaries can be measured by the increase in the capillary hydric conductance and by reduced reflection coefficient of plasma macromolecules. According to Rodoman et al. ${ }^{14}$, the fluorescent albumin test shows that there is a change in the binding sites of albumin in the preoperative period, due to psychological stress, as well as during surgery, although, in this case, there is a less pronounced alteration ${ }^{5,6}$.

The minimum age to be enrolled in the study was 20 years because in younger individuals there is intense anabolism, inherent to growth, which may involve albumin level drop.

The exclusion criteria adopted in this research aimed to reduce the variables that directly influence in albumin synthesis (administration of steroids, radiation therapy, imunnosuppressive drugs, chemotherapy, chronic liver disease with clinical and laboratory changes) or variables that lead to albumin concentration that is not in accordance to actual albumin. For instance, when patients received blood transfusions or were operated as emergency, especially if large volumes of colloids or crystalloids had been administered.

According to the present study, patients aged over 65 years had a more significant decrease in albumin levels than younger individuals, both in major and intermediate surgeries. That result was expected, considering the decrease in organic and metabolic responses as patients get older. This fact emphasizes the need for more intense postoperative care in that age group.

\section{CONCLUSIONS}

Major surgeries are associated to a drop in serum albumin levels immediately after the procedure. Such decrease is more intense in patients aged over 65 years. No relationship was seen related to albumin concentration, gender and skin color.

\section{ACKNOWLEDGEMENTS}

The authors would like to thank the CNPq and FAPEMIG for the financial support to perform this work. 


\section{REFERENCES}

1. Barle $H$, Hallström L, Essén $P$, Thörne $A$, McNurlan MA, Garlick PJ, Wernerman J. The synthesis rate of albumin decreases during laparoscopic surgery. Clin Physiol Funct Imaging. 2004; 24(2): 91-5.

2. Doumas BT, Bayse DD, Carter RJ, Peters T Jr, Schaffer R. A candidate reference method for determination of total protein in serum. I. Development and validation. Clin Chem. 1981; 27:1642-50.

3. Engelman DT, Adams DH, Byrne JG, Aranki SF, Collins JJ JR, Couper GS, Allred EN, Cohn LH, Rizzo RJ. Impact of body mass index and albumin on morbidity and mortality after cardiac surgery. J Thorac Cardiovasc Surg.1999;118(5): 866-73.

4. Faintuch J, Silva FSC, Machado MCC, Cohen RV, Pinotti HW. The nutritional prognosis in pancreatic câncer. $A B C D$ Arq Bras Cir Dig. 1988;3(1):9-12.

5. Franch-Arcas $\mathrm{G}$. The meaning of hypoalbuminaemia in clinical practice. Clin Nutr. 2001;20(3): 265-9.

6. Galatius S, Bent-Hansen L, Wroblewski H, Sorensen VB, Norgaard $\mathrm{T}$, Kastrup J. Plasma disappearance of albumin and impact of capillary thickness in idiopathic dilated cardiomyopathy and after heart transplantation. Circulation. 2000; 102(3):319-25.

7. Gibbs JO, Cull W, Henderson W. Preoperative serum albumin level as predictor of operative mortality and morbidity: results from the national VA surgical risk study. Arch Surg.1999; 134(1): 36-42.

8. Goransson J, Jonsson 0, Lasson A. Screening of concentrations of C-reactive protein and various plasma protease inhibitors preoperatively for the prediction of postoperative complications. Eur J Surg. 1998; 164(2): 89-101.
9. Haupt W, Holzheimer R G, Riese J, Klein P, Hohenberger W. Association of low preoperative serum albumin concentrations and the acute phase response. Eur J Surg.1999; 165(4): 307-13.

10. Pedrosa IV, Burgos MGPA, Souza NC, Morais CN. Aspectos nutricionais em obesos antes e após a cirurgia bariátrica. Rev Col Bras Cir. 2009;36(4):316-22.

11. Pereira AAE. Avaliação imunonutricional do paciente cirúrgico. Ars Curandi Gastro. 1996; 12(1): 24-34.

12. Petroianu A. Cuidados pós-operatórios. In Petroianu $A$, editor. Clínica Cirúrgica. Rio de Janeiro: Revinter; 2001, pp. 17-26.

13. Putwatana P, Reodecha P, Sirapo-ngam Y, Lertsithichai $P$, Sumboonnanonda K. Nutritional screening tools and the prediction of postoperative infectious and wound complications: comparison of methods in presence of risk adjustment. Nutrition. 2005; 21(6): 691-97.

14.Rodoman GV, Dobretsov GE, Shalaeva TI, Naumov EK. Albumin fluorescent test in surgical stress. Bull Exp Biol Med. 2001;131(3):302-4.

15. Santos NSJ, Draibe SA, Kamimura MA, Cuppari L. Albumina sérica como marcador nutricional de pacientes em hemodiálise. Rev Nutr. 2004;17(3): 339-49.

16. Tannus AFST, Carvalho RLV, Suen VMM, Cardoso JB, Okano N, Marchini JS. Energy expenditure after 2- to 3-hour elective surgical operations. Rev Hosp Clin. 2001; 56(1):37-40.

17.Zaina FE, Lopes RW, Souza MRD. A comparison of nutritional status in three time points of liver transplant. Transpl Proceedings. 2004; 36(4): 949-50. 